\title{
Testing an emerging animal model for use in the allergenicity assessment of food
}

\author{
David E Lefebvre ${ }^{1 *}$, Nikia Ross ${ }^{1}$, Laurie Coady ${ }^{1}$, Cheryl Armstrong ${ }^{1}$, Susan Gurofsky ${ }^{1}$, Ivan Curran ${ }^{1}$, Tim Schrader ${ }^{1}$, \\ Don Caldwell ${ }^{2}$, Genevieve S Bondy ${ }^{1}$ \\ From Canadian Society of Allergy and Clinical Immunology Annual Scientific Meeting 2011 \\ Quebec, Canada. 20-23 October 2011
}

\section{Background}

The regulatory assessment of novel food includes tests for allergy. The World Health Organization suggests tests in an animal model of allergy despite the lack of a validated model. We aimed to confirm if $\mathrm{C} 3 \mathrm{H} / \mathrm{HeJ}$ mice would respond to food of high allergenic potential (peanut), but not to food of low allergenic potential (turkey, potato, spinach).

\section{Methods}

In the first study, $\mathrm{C} 3 \mathrm{H} / \mathrm{HeJ}$ mice were orally treated, once per week for two weeks, with adjuvant and 0 or $2 \mathrm{mg}$ of peanut or turkey. A second study used adjuvant and 0 , $0.1,1$ or $2 \mathrm{mg}$ of peanut, potato or spinach. Blood IgE antibodies and spleen interleukin-4 were quantified.

\section{Results}

Mice treated with $2 \mathrm{mg}$ peanut developed peanut-specific IgE levels which were significantly higher than control mice ( $\mathrm{p}<0.001, \mathrm{n}=10$ /group). Mice treated with $2 \mathrm{mg}$ turkey developed a similar IgE response to turkey $(p<0.001$, $\mathrm{n}=10$ /group). In the second study, allergy was only triggered in one of ten mice treated with $2 \mathrm{mg}$ peanut. Two of ten mice exposed to $1 \mathrm{mg}$ potato had a response. There were no IgE responders to spinach. Spleen cells from both the peanut- and the spinach-treated mice secreted more allergy-promoting interleukin- 4 than controls ( $\mathrm{p}<0.01, \mathrm{n}=7-24 /$ group). Levels were not modified in potato-treated mice.

\section{Conclusions}

$\mathrm{C} 3 \mathrm{H} / \mathrm{HeJ}$ mice developed food allergy markers to peanut. However, the incidence varied between experiments.

${ }^{1}$ Toxicology Research Division, Bureau of Chemical Safety, Food Directorate, Health Canada, Ottawa, ON, K1A OL2, Canada

Full list of author information is available at the end of the article
Some mice developed a similar response to foods with low allergenic potential. Thus, this model may not be appropriate for safety assessment of novel food.

\section{Author details}

${ }^{1}$ Toxicology Research Division, Bureau of Chemical Safety, Food Directorate, Health Canada, Ottawa, ON, K1A OL2, Canada. ${ }^{2}$ Scientific Services Division, Bureau of Chemical Safety, Food Directorate, Health Canada, Ottawa, ON, K1A OL2, Canada.

Published: 14 November 2011

doi:10.1186/1710-1492-7-S2-A1

Cite this article as: Lefebvre et al: Testing an emerging animal model for use in the allergenicity assessment of food. Allergy, Asthma \& Clinical Immunology 2011 7(Suppl 2):A1.
Submit your next manuscript to BioMed Central and take full advantage of:

- Convenient online submission

- Thorough peer review

- No space constraints or color figure charges

- Immediate publication on acceptance

- Inclusion in PubMed, CAS, Scopus and Google Scholar

- Research which is freely available for redistribution

\section{() Biomed Central}

C Biomed Central 